Jurnal Keuangan dan Perbankan, Vol.19, No.3 September 2015, hlm. 400- 408

Terakreditasi SK. No. 040/P/2014

http://jurkubank.wordpress.com

\title{
REAKSI ASIM ETRI ATAS SINYAL BELI DAN JUAL ANALISIS TEKNIS: PENGUJIAN BIAS KONFIRMASI SEBELUM PENGUMUMAN LABA*
}

\author{
Dedhy Sulistiawan \\ Jurusan Akuntansi Fakultas Bisnis dan Ekonomika Universitas Surabaya
}

\begin{abstract}
The main purpose of this study is to examine asymmetry reaction on buying and selling technical analysis signal beforeearnings announcements. Behavioral financetheory is used in explaining why confirmation bias stimulates asymmetry reaction to stock return. To support that idea, this articleuses technical analysis as an important feature in testing confirmation bias. U sing Indonesian stock market data, the results show that technical analysis signal producehigher return in buying signal than selling signal. Investors givedifferent attention in anticipating technical analysis signal around earnings announcements. This finding contributes to behavioral financeand technical analysis studies.
\end{abstract}

Keyw ords: Technical analysis, asymmetry reaction, confirmation bias, and earnings announcements.

\section{PENDAHULUAN}

Keputusan yang ideal adalah keputusan yang berbasis pada rasionalitas. Teori pasar efisien yang mendominasi riset pasar modal mengasumsikan bahwa keputusan investor bersifat rasional. Berbeda dengan aliran efisiensi pasar tersebut, studi ini meyakini adanya potensi bias dalam keputusan investor. Untuk menjelaskannya, teori keuangan keperilakuan digunakan sebagai dasar dari studi ini. Teori keuangan keperilakuan ini menggunakan asumsi bahwa keputusan manusia cenderung bias. Bias ini disebabkan karena aspek keterbatasan rasional (bounded rationality) manusia (Bazerman, 1994). Teori ini juga merupakan alternatif dari ide efisiensi pasar karena investor seringkali mengambil keputusan yang tidak berbasis pada aspek rasionalitas.

Reaksi asimetri atas suatu informasi juga merepresentasikan adanya bias dalam keputusan berbasis informasi akuntansi, misal Conrad et al. (2002), Mian dan Sankarasguruswamy (2012), Ho dan Sequeira (2007), dan Xu (2008). Jika studi

Koresponden dengan Penulis

Dedhy Sulistiawan: Telp:

E-mail: dedhy@ubaya.ac.id 


\section{Reaksi Asimetri Atas Sinyal Beli dan Jual Analisis Teknis: Pengujian Bias Konfirmasi Sebelum Pengumuman Laba}

Dedhy Sulistiawan

sebelumnya berfokus pada reaksi asimetri saat pengumuman informasi fundamental, studi ini berfokus pada reaksi asimetri saat sinyal analisis teknis sebelum pengumuman laba.

Pengujian atas reaksi asimetri pada sinyal analisis teknis ini penting karena analisis teknis adalah strategi perdagangan yang penting di bursa berkembang (Fifield, Power, dan Sinclair, 2005; A hmed dan Goldreyer, 2000). Analisis teknis juga memiliki kinerja bagus di Indonesia dibandingkan negara maju (McKenzie, 2007; Hartono dan Sulistiawan, 2014).

Dalam konteks riset analisis teknis, studi Sulistiawan dan Hartono (2014) dan Sulistiawan et al. (2014) menunjukkan bahwa sinyal analisis teknis sebelum pengumuman laba adalah sinyal yang dominan dan bahkan memiliki potensi menjadi informasi pesaing pengumuman laba. Studi ini melengkapi studi tersebut dengan menguji reaksi asimetri atas sinyal beli dan jual yang dihasilkan di sekitar tanggal pengumuman laba.

Reaksi asimetri yang terjadi ini merepresentasikan adanya bias konfirmasi. Bias konfirmasi ini terjadi ketika seseorang cenderung sangat memperhatikan suatu bukti atau berita yang sesuai dengan keyakinannya, namun cenderung mengabaikan bukti atau berita yang tidak sesuai dengan keyakinannya (Kassin et al., 2013). Dalam konteks penggunaan sinyal analisis teknis yang muncul sebelum pengumuman Iaba, sinyal beli lebih diperhatikan dibandingkan sinyal jual karena pada perioda pengumuman laba, harga saham cenderung bias naik (Sugiri dan Sumiyana, 2009). Efeknya dampak sinyal beli terhadap return lebih besar dibandingkan dampak sinyal jualnya. Studi ini memprediksi bahwa return yang dihasilkan sinyal beli analisisteknisyang muncul sebelumpengumuman laba lebih besar dibandingkan sinyal jualnya.

Terdapat beberapa kontribusi yang diharapkan dari studi ini. Dari perspektif metodologi, studi ini mengembangkan teknik penelitian Bessembinder dan Chan (1995) dan Balsara, Chen, dan Zheng (2005) yang menggunakan data runtun waktu harga saham dan tidak menggunakan data fundamental. Studi ini melengkapinya dengan pengujian saat peristiwa penting di pasar modal, yaitu pengumuman laba. Secara praktis, studi ini memberikan panduan penggunaan sinyal beli dan jual analisis teknis di sekitar pengumuman laba. Secara teoritis, studi ini membangun jembatan antara studi analisis teknis dan pengumuman laba, sebuah area penelitian yang masih prospektif.

Artikel ini disajikan dalam beberapa bagian. Bagian kedua menjelaskan tentang landasan teori, kajian empiris dan pengembangan hipotesis. Bagian ketiga menjelaskan tentang metode yang digunakan dalam penelitian ini. Bagian keempat membahas hasil penelitian, dan bagian terakhir membahaskesimpulan dan saran untuk penelitian berikutnya.

\section{LANDASAN TEORI, KAJIAN EM PIRIS DAN PENGEMBANGAN HIPOTESIS}

\section{Bias Keputusan Investasi}

Teori keuangan keperilakuan membahastentang inefisiensi pasar sekuritas yang berdasarkan keputusan investor yang tidak selalu rasional. Studi ini juga meyakini bahwa keputusan investor juga bias. Bias keputusan ini disebabkan aspek keterbatasan rasional (bounded rationality) manusia yang muncul karena (1) informasi yang tidak lengkap atas berbagai alternatif keputusan. (2) kompleksitas informasi, dan (3) risiko dan ketidakpastian (Simon, 1972). Hal tersebut selaras dengan konteks keputusan investor di pasar modal.

Terdapat banyak sekali bias dalam keputusan (Bazerman, 1994). Studi ini berfokus pada confirmation bias (bias konfirmasi), yaitu bias keputusan yang disebabkan seseorang cenderung mencari bukti yang mengkonfirmasi keyakinannya (Kassin etal., 2013). Bias ini relevan di pasar modal karena setiap hari mereka mendapatkan banyak informasi baru untuk mendukung keputusan mereka. 


\section{Jurnal Keuangan dan Perbankan | KEUANGAN}

Vol. 19, N o.3, September 2015: 400-408

Studi berbasis teori keuangan keperilakuan yang membahas reaksi asimetri di sekitar pengumuman labatelah banyak dilakukan (Conrad et al., 2002; Mian dan Sankarasguruswamy, 2012; Ho dan Sequeira, 2007; Xu, 2008). Jika studi-studi tersebut berfokus pada aspek berita dan dan peristiwa pengumuman laba, studi ini memberikan perhatian pada sinyal anal isis teknis yang muncul sebelum pengumuman laba. Fokus perhatian tersebut diharapkan akan memberikan kontribusi penting dalam jalur penelitian reaksi asimetri di sekitar pengumuman laba.

\section{Pengumuman Laba dan Analisis Teknis}

Studi analisis teknis padaumumnya menggunakan data runtun waktu dengan perioda panjang (Sweneey, 1988; Brock et al. 1992; Bessembinder dan Chan, 1995; A hmed et al. 2000; McKenzie, 2007; Wong et al. 2003; Fifield et al. 2005; Balsara et al. 2007; Milionis dan Papanagiotou, 2008; M etgalchi et al. 2012). H anya sedikit studi yang menganalisis kinerja analisis teknis dengan studi peristiwa, misalnya Sulistiawan dan Hartono (2014) dan Sulistiawan et al. (2014). Keduanya membahas sinyal anal isis teknis di sekitar pengumuman laba. Studi ini mengembangkannya dengan menganal isis reaksi asimetri atas sinyal beli dan jual yang dihasilkan analisis teknis sebelum pengumuman laba. Sinyal beli dan sinyal jual sebelum pengumuman laba diharapkan direaksi secara berbeda.

\section{Pengembangan Hipotesis}

Terdapat beberapa alasan penting adanya reaksi asimetri atas sinyal beli dan jual analisis teknis sebelum pengumuman laba. Studi ini meyakini terjadinya bias konfirmasi. Seseorang cenderung menggunakan informasi yang sama dengan kepentingannya. Informasi yang berbeda dengan kepentingannya cenderung tidak diperhatikan. Dalam perioda pengumuman laba, sinyal beli lebih dipertimbangkan dibandingkan sinyal jual karena adanya adanya keyakinan akan harga di sekitar pengumuman cenderung bias naik (Sugiri dan Sumiyana, 2009)

A lasan lain terjadinya reaksi asimetri adalah adanya perbedaan tindakan pelaku pasar. Pada sinyal beli, cal on pembeli saham $x$ ada dua pihak, yaitu orang yang belum dan sudah memiliki saham $x$. Pada sinyal jual, cal on penjual hanya satu pihak yaitu orang yang sudah memiliki saham tersebut. Orang yang belum memiliki saham tersebut tidak bisa membuat tekanan jual karena batasan penjual an short-selling, misalnya pengumuman BEI No. 00666/ BEI.PSH / 12-2011 tentang aturan saham tertentu yang bisa ditransaksikan serta aturan persyaratan transaksi short selling di Kep-00009BEI/ 01-2009. Aturan tersebut juga ditetapkan oleh BAPEPAM-LK dalam Peraturan N omor V.D.6. Tidak tersedianya menu short-selling pada menu perdagangan saham on-line juga memberikan batasan transaksi ini bagi investor retail.

Dukungan studi analisis teknis sebelumnya juga meyakinkan mengenai adanya reaksi asimetri ini. Berbasis studi menggunakan data runtun waktu, Bessembinder dan Chan (1995) dan Balsara, Chen, dan Zheng (2005) menunjukkan peran sinyal beli yang lebih superior dibandingkan sinyal jual. Dalamstudi ini sinyal yang dianal isis adalah sinyal anal isis teknis di sekitar pengumuman laba. H arga di hari munculnya sinyal analisis teknis sebelum pengumuman laba dibandingkan dengan harga di hari saat munculnya sinyal analisis teknis setelah pengumuman laba.

Berdasarkan beberapa pertimbangan di atas, studi ini memprediksikan bahwa Sinyal beli analisis teknis yang muncul sebelum pengumuman laba menghasilkan return yang lebih besar dibandingkan sinyal jualnya.

\section{METODA}

\section{Data dan Sampel}

Penelitian ini menggunakan data bursa Indonesia. Bursa Indonesia adalah bursa berkem- 
bang yang menghasilkan kinerja yang bagus bagi sinyal analisis teknis (McKenzie, 2007; Hartono dan Sulistiawan, 2014). Atas dasar itu pengujian dalam riset ini menggunakan sinyal analisis teknis sebelum pengumuman laba.

Sampel penelitian ini ditentukan dengan kriteria (1) emiten di Bursa Efek Indonesia (BEI), (2) tersedianya tanggal surat penerimaan laporan keuangan dari emiten kepada pengelola bursa, (3) tersedianya laporan keuangan dan harga saham tersedia, (4) memiliki volume perdagangan di sekitar tanggal pengumuman laba, dan (5) tidak memiliki peristiwa pengganggu di sekitar tanggal pengumuman yang memengaruhi reaksi harga pengumuman laba.

\section{Prosedur Penelitian}

Prosedur yang dilakukan untuk menjawab tujuan studi dalam dalam penelitian ini disajikan sebagai berikut.

1. Menentukan model empiris penelitian.

Hipotesis pertama diuji dengan membandingkan return dari sinyal beli dan sinyal jual analisis teknis sebelum pengumuman laba. Model empiris dari hipotesis penelitian ini adalah sebagai berikut.

H1: $\mathbf{R t b t}_{\mathrm{i}, \mathrm{t}, \mathrm{buy}}>\mathbf{R t b t}_{\mathrm{i}, \mathrm{t} \text {,ell. }}$

$\mathrm{Rtbt}_{\mathrm{i}, \mathrm{t}, \mathrm{buy}}\left(\mathrm{Rtbt}_{\mathrm{i}, \mathrm{t}, \text { sell }}\right)$ adalah return analisis teknis dari sinyal beli (jual) yang muncul sebelum pengumuman laba.

2. Menentukan tanggal pengumuman laba untuk setiap emiten.

Tanggal tersebut digunakan sebagai sampel penelitian. Tanggal ini digunakan sebagai dasar untuk menentukan saat munculnya sinyal analisis teknis sebelum pengumuman laba.

3. Membuat grafik analisis teknis dengan menggunakan indikator simple moving average (SMA). Garis indikator SMA ditentukan dari berdasarkan rumus berikut.
$\operatorname{SMA}(\mathrm{n})_{\mathrm{i}}=\left(\mathrm{P}_{\mathrm{n}, \mathrm{i}}+\mathrm{P}_{\mathrm{n}-1, \mathrm{i}}+\ldots+\mathrm{P}_{1, \mathrm{i}}\right) / \mathrm{n}$

$\mathrm{P}_{\mathrm{n}, \mathrm{i}}$ adalah harga saham perusahaan i $\mathrm{n}$ hari yang lalu. $\mathrm{P}_{1, \mathrm{i}}$ adalah harga saham perusahaan i satu hari yang lalu. $\mathrm{n}$ adalah perioda yang digunakan dalam indikator (dalam hari). Nilai $n$ yang digunakan adalah 5 dan 10 sesuai temuan pada studi Milionis dan Papanagiotou (2008).

4. Menentukan saat terjadinya sinyal analisis teknis sebelum pengumuman laba.

Adapun penentuan saat terjadinya sinyal disajikan pada persamaan berikut.

$\mathrm{S}_{\mathrm{SBi}}=\left(\mathrm{P}_{0, \mathrm{i}}>\mathrm{SMAn}_{0, \mathrm{i}} \mid \mathrm{P}_{-1, \mathrm{i}}<\mathrm{SMAn}_{-1, \mathrm{i}}\right)$

$\mathrm{S}_{\mathrm{Sji}}=\left(\mathrm{P}_{0, \mathrm{i}}<\mathrm{SMAn}_{0, \mathrm{i}} \mid \mathrm{P}_{-1, \mathrm{i}}>\mathrm{SMAn}_{-1, \mathrm{i}}\right)$

$S_{S B i}\left(t_{S j i}\right)$ adalah sinyal beli (jual) yang muncul pada saham i di suatu hari perdagangan. Sinyal beli muncul ketika harga $\left(\mathrm{P}_{\mathrm{o}, \mathrm{i}}\right)$ memotong ke atas garis indikator $\left(\mathrm{SMAn}_{\mathrm{o}, \mathrm{i}}\right)$. Sebaliknya, sinyal jual terjadi ketiga harga $\mathrm{P}_{\mathrm{o}, \mathrm{i}}$ memotong ke bawah SMAn $n_{0, \mathrm{i}} \mathrm{P}_{0, \mathrm{i}}$ adalah harga saat garis harga saham i pada hari ke- $0 . \mathrm{P}_{-1, \mathrm{i}}$ adalah harga saat garis harga saham i pada satu hari sebelum hari ke-0. SMAn $n_{0, \mathrm{i}}$ adalah nilai SMAn saat garis harga saham i yang pertama kali memotong garis SMA. SMAn ${ }_{-1, i}$ adalah nilai SMAn saat satu hari sebelum garis harga saham $i$ memotong garis SMA. $\mathrm{P}_{0, \mathrm{i}}$ adalah harga saat garis harga saham i pada hari ke- $0 . \mathrm{P}_{-1, \mathrm{i}}$ adalah harga saat garis harga saham i pada satu hari sebelum hari ke-0. SMAn ${ }_{0, i}$ adalah nilai SMAn saat garis harga saham i yang pertama kali memotong garis SMA. SMAn ${ }_{-1, i}$ adalah nilai SMAn saat satu hari sebelum garis harga saham i memotong garis SMA.

5. Menentukan return berbasis sinyal analisis teknis sebelum pengumuman. Perhitungannya sebagai berikut.

$\mathbf{R t b t}_{i, t, b u y}=\left(\mathbf{P}_{a, i, t}-\mathbf{P}_{b, i, t}\right) / \mathbf{P}_{b, i, t}$

$\mathbf{R t b t}_{\mathrm{i}, \mathrm{t} \text {, sell }}=-\left[\left(\mathbf{P}_{\mathrm{a}, \mathrm{i}, \mathrm{t}}-\mathbf{P}_{\mathrm{b}, \mathrm{i}, \mathrm{t}}\right) / \mathbf{P}_{\mathrm{b}, \mathrm{i}, \mathrm{t}}\right]$

$\operatorname{Rtbt}_{i, t, b u y}\left(R t_{i, t, \text { sell }}\right)$ adalah return yang dihasilkan dari sinyal beli (jual) pada saham i di hari $\mathrm{t}$ sebelum pengumuman laba dan diakhiri saat 


\section{Jurnal Keuangan dan Perbankan | KEUANGAN}

Vol. 19, N o.3, September 2015: 400-408

sinyal jual (beli) setelah pengumuman laba di tahun t. $\mathrm{P}_{\mathrm{b}, \mathrm{i}}\left(\mathrm{P}_{\mathrm{a}, \mathrm{i}}\right)$ adalah harga sahami pada saat sinyal analisis teknis sebelum (setelah) pengumuman laba di tahun $\mathrm{t}$.

6. Pengujian Hipotesis.

Pengujian ini dilakukan dengan membandingkan return dari sinyal beli dan jual analisis teknis seperti yang disajikan pada persamaan (1). Pengujian hipotesis menggunakan return pada persamaan (5) dan (6). Penggunaan return sesuaian pasar dan return abnormal berbasis model pasar juga digunakan dalam pengujian $\mathrm{H}$ 1. Return sesuaian pasar adalah return saham setelah dikurangi return pasar. Return abnormal adalah selisih return dan return ekspektasian. Return ekspektasian ditentukan dengan menggunakan model pasar. Jika return analisis teknis dari sinyal beli yang muncul sebelum pengumuman laba lebih besar daripadasinyal jualnya maka hipotesisterdukung. Dampak dari sinyal terhadap returnnya juga diuji dengan mengontrol ukuran perusahaan. Pengujian dilakukan dengan persamaan sebagai berikut.

Rtbt $_{1, \mathrm{t}}=\mathrm{a}+\mathrm{b} 1$ sinyal + b2 Lnmcap.

Rtbt $t_{1, t}$ adalah return yang dihasilkan dari sinyal analisis teknis yang muncul sebelum pengumuman laba. Sinyal adalah sinyal beli (jual) analisis teknis sebelum pengumuman laba. Sinyal bernilai 1 (0) jika sinyal beli (0). Lnmcap dihitung dari kapitalisasi pasar perusahaan i di tanggal laporan keuangan. Harapannya koefisien b1 signifikan secara statistis.

\section{HASIL DAN PEMBAHASAN}

\section{Hasil Penelitian}

Studi ini menghipotesiskan bahwapadasinyal analisis teknis yang muncul sebelum dan setelah pengumuman laba, return atas sinyal beli lebih besar dibandingkan return atas sinyal jual. Return yang menguntungkan dari sinyal beli (jual) terjadi

Tabel II Hasil Pengujian H1 pada Sampel Sinyal SM A5

\begin{tabular}{ccccccc}
\hline Rtbt $_{i, \mathbf{t}}$ & sinyal & N & Rata-rata & D eviasi Standar & Statistik t & Sig. \\
\hline Rtbt $_{i, \mathrm{t}} \mathbf{1}$ & Beli & 550 & 0,0381 & 0,08482 & 6,902 & 0,000 \\
& Jual & 436 & 0,0019 & 0,07769 & & \\
Rtbt $_{i, \mathrm{t}} 2$ & Beli & 550 & 0,0331 & 0,08482 & 6,902 & 0,000 \\
& Jual & 436 & $-0,0031$ & 0,07769 & & \\
Rtbt $_{i, \mathrm{t}} 3$ & Beli & 553 & 0,0207 & 0,08206 & 1,751 & 0,040 \\
& Jual & 436 & 0,0117 & 0,07670 & & \\
Rtbt $_{i, 4} 4$ & Beli & 500 & 0,0231 & 0,08513 & 2,473 & 0,007 \\
& Jual & 390 & 0,0097 & 0,07359 & & \\
\hline
\end{tabular}

Keterangan:

a. Sampel penuh adalah sampel penelitian menggunakan semua data yang memenuhi persyaratan setelah dikurangi pencilan yang terletak di luar batas atas dan bawah.Batas atas (bawah) ditentukan berdasarkan nilai rata-rata yang ditambah (dikurangi) dua kali deviasi standar dari sampel penuh.

b. Rtbt $_{\mathrm{i}, \mathrm{t}} 1$ adalah return analisis teknis yang dihitung berdasarkan selisih harga saat sinyal analisis teknis setelah pengumuman laba dengan harga saat sinyal analisis teknis sebelum pengumuman laba yang kemudian dibagi dengan harga saat sinyal analisis teknis sebelum pengumuman laba. Perhitungan return tersebut berlaku untuk sampel dengan sinyal beli analisis teknis sebelum pengumuman laba. Untuk sampel dengan sinyal jual sebelum pengumuman laba, nilai return yang dihasilkan dikalikan minus satu.

c. Rtbt ${ }_{i, t} 2$ adalah Rtbt ${ }_{i, t} 1$ dikurangi biaya transaksi sebesar 0,5\%. Di Indonesia, kebanyakan sekuritas memberikan biaya sebesar 0,15\% dan $0,25 \%$ untuk jual bagi investor retail. Artinya, biaya transaksi sebesar 0,5\% adalah nilai konservatif pengurang return.

d. Rtbt $_{i, t} 3$ adalah Rtbt 1 it, 1 dikurangi return pasar. Return pasar yang dirujuk adalah return dari Indeks Harga Saham Gabungan (IHSG).

e. Rtbt $_{i, t} 4$ adalah Rtbt $_{i, t} 1$ dikurangi return ekspektasian. Return ekspektasian dihitung dengan model pasar dengan perioda estimasi satu tahun. 
ketika harga saat sinyal beli (jual) sebelum pengumuman laba lebih rendah (tinggi) dari pada harga saat sinyal jual (beli) setelah pengumuman laba. Dengan kata lain harga yang naik (turun) setelah sinyal beli (jual) menghasilkan return yang menguntungkan. Untuk membandingkan return antara keduanya, maka return atas sinyal jual dikalikan dengan minus satu.

Hasil pengujian hipotesis ini disajikan di Tabel II. Teknik perhitungan return yang digunakan adalah (1) return yang hanya mempertimbangkan selisih harga $\left(\mathrm{Rtbt}_{\mathrm{i}, \mathrm{t}} 1\right)$, (2) return yang mempertimbangkan biaya transaksi sebesar $0,5 \%$ untuk transaksi beli dan jual ( $\mathrm{Rtbt}_{i, \mathrm{t}}$ 2), (3) return yang disesuaikan dengan return pasar $\left(\mathrm{Rtbt}_{\mathrm{i}, \mathrm{t}} 3\right)$, dan (4) return taknormal berbasis model pasar $\left(\operatorname{Rtbt}_{\mathrm{i}, \mathrm{t}} 4\right)$.

Pada Rtbt ${ }_{i, t} 1$ dan $\mathrm{Rtbt}_{\mathrm{i}, \mathrm{t}}$, variansi antara kelompok sinyal beli dan jual berbeda signifikan. Namun pada $\mathrm{Rtbt}_{\mathrm{i}, \mathrm{t}} 3$ dan $^{\mathrm{R} t b t_{\mathrm{i}, \mathrm{t}}}$, variansi antara kelompok sinyal beli dan jual secara statistis tidak berbeda. Secara umum, tampilan hasil pengujian di tabel tersebut menunjukkan dukungan terhadap hipotesis penelitian.

Nilai Rtbt $_{i, t} 1$ dari sinyal beli adalah 3,81\% dan $\mathrm{Rtbt}_{\mathrm{i}, \mathrm{t}} 1$ dari sinyal jual adalah sebesar 0,19\%. Pada $\operatorname{Rtbt}_{\mathrm{i}, \mathrm{t}} 2$, sinyal beli menguntungkan namun sinyal jual menghasilkan return kurang dari nol. Pada $\operatorname{Rtbt}_{\mathrm{i}, \mathrm{t}}$ 3, return dari sinyal belinya adalah
$2,07 \%$ dan return sinyal jual adalah sebesar 1,07\%. Temuan yang sama juga terjadi pada $\mathrm{Rtbt}_{\mathrm{i}, \mathrm{t}} 4$ yang menunjukkan return dari sinyal beli lebih besar daripada return sinyal jual.

Pada pengujian $\mathrm{Rtbt}_{\mathrm{i}, \mathrm{t}}$, Rtbt $_{\mathrm{i}, \mathrm{t}}$ 2, dan $\mathrm{Rtbt}_{\mathrm{i}, \mathrm{t}}$ 4 , perbedaan return atas sinyal beli dan return atas sinyal jual signifikan secara statistis pada level 1\%. Pada pengujian $\mathrm{Rtbt}_{\mathrm{i}, \mathrm{t}}$, perbedaannya signifikan secara statistis pada level $5 \%$. Temuan tersebut menunjukkan bahwa terjadi asimetri return atas sinyal beli dan jual yang muncul sebelum pengumuman laba.

Pengujian hipotesis yang dilakukan sebelumnya menggunakan sinyal SMA5. Studi ini melengkapinya dengan pengujian dengan sinyal SMA10. Hasil pengujian hipotesis berbasis sinyal SMA10 disajikan di Tabel III.

Nilai Rtbt $_{\mathrm{i}, \mathrm{t}} 1$ dari sinyal beli adalah 5,88\% dan Rtbt $_{i, t} 1$ dari sinyal jual adalah sebesar 2,53\%. Pada Rtbt $_{i, t} 2$, sinyal beli menghasilkan return 5,38\% dan sinyal jual menghasilkan return 2,03\%.Pada $\operatorname{Rtbt}_{\mathrm{i}, \mathrm{t}}$, return dari sinyal belinya adalah 4,15\% dan return sinyal jual adalah sebesar $0,8 \%$. Temuan yang sama juga terjadi pada $\mathrm{Rtbt}_{\mathrm{i}, \mathrm{t}} 4$ yang menunjukkan return dari sinyal beli lebih besar daripada return sinyal jual.

Pada semua pengujian return, perbedaan return atas sinyal beli dan return atas sinyal jual

Tabel III Hasil Pengujian H1 pada Sampel Sinyal SMA10

\begin{tabular}{rlrrrrr}
\hline \multicolumn{1}{c}{ Rtbt $_{\mathbf{i}, \mathbf{t}}$} & sinyal & N & \multicolumn{1}{c}{ Rata-rata } & Deviasi Standar & \multicolumn{1}{c}{ Statistik $\mathbf{~}$} & \multicolumn{1}{c}{ Sig. } \\
\hline Rtbt $_{\mathrm{i}, \mathrm{t}} 1$ & Beli & 576 & 0,0588 & 0,11710 & 4,543 & 0,000 \\
& Jual & 398 & 0,0253 & 0,10729 & & \\
Rtbt $_{\mathrm{i}, \mathrm{t}} 2$ & Beli & 576 & 0,0538 & 0,11710 & 4,543 & 0,000 \\
& Jual & 398 & 0,0203 & 0,10729 & & \\
Rtbt $_{\mathrm{i}, \mathrm{t}} 3$ & Beli & 581 & 0,0415 & 0,13130 & 3,947 & 0,000 \\
& Jual & 394 & 0,0080 & 0,12740 & & \\
Rtbt $_{\mathrm{i}, \mathrm{t}} 4$ & Beli & 532 & 0,0462 & 0,13082 & 4,056 & 0,000 \\
& Jual & 369 & 0,0108 & 0,12637 & & \\
\hline
\end{tabular}




\section{Jurnal Keuangan dan Perbankan | KEUANGAN}

Vol. 19, N o.3, September 2015: 400-408

signifikan secara statistis pada level 1\%. Sinyal beli menghasilkan return yang lebih besar dibandingkan sinyal jual. Temuan tersebut menunjukkan bahwa terjadi asimetri return atas sinyal beli dan jual yang muncul sebelum pengumuman laba baik pada strategi SMA 5 maupun SMA 10.

Pengujian hipotesisjuga dilakukan dengan sampel portofolio yang ditentukan secara acak pada strategi SMA 5 dan SMA 10. Hasilnya menunjukkan kesimpulan yang sama. $\mathrm{H}$ al ini menunjukkan bahwa pada semua sub sampel, hasil pengujian selanjutnya juga terdukung secara statistis. Return atas sinyal beli lebih besar daripada return atas sinyal jual.

Pengujian hipotesis dengan menggunakan analisis regresi disajikan di Tabel IV. Pada koefisien sinyal, secara statistis memiliki pengaruh terhadap return berbasis sinyal SMA5 analisis teknis yang muncul sebelum pengumuman laba. Berdasarkan pengujian dengan berbagai perhitungan return, hasilnyamenunjukkan dukungan terhadap hipotesis.

Pengujian hipotesis juga dilakukan dengan menggunakan sampel SMA10. Hasilnya juga menunjukkan kesimpulan yang seragam. Hal ini menunjukkan bahwa temuan di studi ini robust (tegar) pada penentuan return yang berbeda, termasuk indikator analisis teknis yang berbeda.

Dalam proses pengujian, tidak ditemukan masal ah dalam pengujian asumsi klasik. M eskipun begitu, uji whitejuga untuk melihat persistensi koefisien regresi.. Hasilnya pengujiannya tidak mengubah kesimpulan statistis.

\section{Analisis Hasil Penelitian}

Studi Sulistiawan dan Hartono (2014) telah menunjukkan bahwa sinyal analisis teknis yang muncul sebelum pengumuman laba menghasilkan kinerja yang baik. Studi ini mengembangkan studi sebelumnya tersebut dengan memisahkan reaksi atas sinyal beli dan sinyal jualnya.

Reaksi asimetri atas sinyal beli dan jual analisis teknis yang muncul sebelum pengumuman laba tersebut menunjukkan tendensi adanya bias konfirmasi. Sugiri dan Sumiyana (2009) menunjukkan bahwa harga saham di sekitar pengumuman laba cenderung untuk bias naik. Keoptimisan tersebutmembuat investor mengabaikan sinyal jual dibandingkan sinyal beli karena munculnya sinyal jual bukanlah informasi yang mereka harapkan akan muncul. Sebaliknya, munculnya sinyal beli merupakan informasi yang diharapkan investor sehingga mereka akan membobot sinyal tersebut lebih besar dibandingkan sinyal jualnya.

Bias penting lain dari adanya return asimetri tersebut adalah fenomena efek disposisi. Sinyal jual yang muncul sebelum pengumuman laba diawali dengan penurunan harga. J ikainvestor tel ah memiliki saham tersebut sebelumnya, maka ada probabilitas yang besar bahwa nilai saham yang dibeli oleh investor tersebut mengalami penurunan. Ketika sinyal jual muncul dan harganya menurun, maka investor yang telah memiliki saham akan cenderung enggan untuk menjual nya. Fenomena efek disposisi ini telah ditunjukkan oleh Odean (1998), Shefrin dan Statman (1994), dan Weber dan

Tabel IV Pengujian Reaksi Asimetri saat Munculnya Sinyal SM A5

\begin{tabular}{|c|c|c|c|c|c|c|c|c|c|c|c|c|}
\hline & \multicolumn{3}{|c|}{ Rtbt $_{i, \mathrm{t}} 1$} & \multicolumn{3}{|c|}{ Rtbt $_{i, \mathrm{t}} 2$} & \multicolumn{3}{|c|}{ Rtbt $_{i, t} 3$} & \multicolumn{3}{|c|}{ Rtbt $_{i, \mathrm{t}} 4$} \\
\hline & Koef. & Stat. $\mathbf{t}$ & Sig & Koef. & Stat. t & Sig & Koef. & Stat. t & Sig & Koef. & Stat. t & Sig \\
\hline$C$ & 0.033 & 2.264 & $* *$ & 0.022 & 0.015 & t.s & 0.033 & 2.328 & ** & 0.033 & 2.264 & ** \\
\hline SINYAL & 0.027 & 2.720 & $* * *$ & 0.057 & 0.010 & $* * *$ & 0.022 & 2.309 & $* *$ & 0.027 & 2.720 & $* * *$ \\
\hline $\begin{array}{l}\text { LN M CAP } \\
\text { Durbin- }\end{array}$ & -0.003 & -1.301 & t.s & -0.004 & 0.002 & t.s & -0.002 & -1.056 & t.s & -0.003 & -1.301 & t.s \\
\hline W atson & \multicolumn{3}{|c|}{1.818} & \multicolumn{3}{|c|}{1.829} & \multicolumn{3}{|c|}{1.815} & \multicolumn{3}{|c|}{1.818} \\
\hline
\end{tabular}




\section{Reaksi Asimetri Atas Sinyal Beli dan Jual Analisis Teknis: Pengujian Bias Konfirmasi Sebelum Pengumuman Laba \\ Dedhy Sulistiawan}

Camerer (1998). Namun studi ini mengembangkannyapadapenggunaan sinyal analisisteknis di sekitar pengumuman laba.

Studi ini mencoba melengkapinya dengan menguji perbedaan sinyal beli dan jual setelah tanggal pengumuman laba. Hasilnya menunjukkan tidak ada perbedaan antara return berbasis sinyal beli dan jual analisis teknis setelah pengumuman laba. Tidak adanya perbedaan ini karena disebabkan harga setelah pengumuman laba tidak menghasilkan fluktuasi yang kuat untuk menghasilkan sinyal beli dan jual. Sinyal analisis teknis tidak lagi didukung oleh informasi fundamental yang beredar di pasar.

\section{KESIMPULAN DAN SARAN}

Berdasarkan hasil dan analisis data, kesimpulan dari studi ini adalah terjadinya reaksi asimetri atas sinyal beli dan jual analisis teknis sebelum pengumuman laba. Sinyal beli sebelum pengumuman laba menghasilkan return yang lebih besar dibandingkan sinyal jualnya. Hal ini terjadi karena bias konfirmasi. A tensi investor lebih besar pada sinyal beli dibandingkan sinyal jual. Ketika menerima sinyal jual investor cenderung mengabaikannya karena mereka berkepentingan terhadap kenaikan harga.

Temuan ini memiliki implikasi praktis dan teoritis. Secara praktis, studi ini memberikan kontribusi pada teknik perdagangan saham di sekitar pengumuman laba. Secara teoritis, studi ini memberikan dukungan pada studi analisis teknis yang tidak meyakini teori pasar efisien, melainkan studi keuangan keperilakuan yang mengakui adanya potensi bias dal am keputusan investor secara agregat.

Untuk pengembangan penelitian berikutnya, studi Mian dan Sankarasguruswamy (2012) dan Conrad et al. (2002) perlu dikembangkan dengan sentimen berbasis analisis teknis. studi ini. Keputusan yang bias mungkin mempengaruhi respon investor dalam menerima berita kejutan laba. Pengetahuan tersebut diperlukan untuk memikirkan aspek mitigas dari bias keputusan tersebut.

\section{DAFTAR PUSTAKA}

Ahmed, P., K. Beck, dan Goldreyer, E., 2000, “Can Moving Average Technical Trading Strategies Help in Volatile and Dedining Markets? A Study of Some Emerging Asian Markets", $M$ anagerial Finance, Vol 26, pp. 49-62.

Balsara, N.J., Chen G., dan Zheng, C., 2005, “An Examination of the Random Walk Model and Technical Trading Rules", Journal of Business \& Economics, Vol 46, pp. 43-63.

Bazerman, 1994, “Judgment in M anagerial D ecision M aking", Willey \& Sons. Inc.

Bessembinder, H., dan Chan. K., 1995, “The Profitability of Trading Rules in the Asian Stock Markets", Pasific-Basin Finance Journal, Vol 3, pp. 257-284.

Brock,W., Lakonishok, J., dan LeBaron, B., 1992, “Simple Technical Trading Rules and the Stochastic Properties of Stock Returns", Journal of Finance, Vol 47, pp. 1731-1764.

Conrad, J., Cornell, B., dan Landsman, W.R., 2002, “When is Bad N ews Really Bad News?", Journal of Finance, Vol 57, pp. 2507-2532.

Fifield, S.G.M., Power, D.M., dan Sinclair, CD., 2005, “An Analysis of Trading Strategies in Eleven European Stock Markets", TheE uropean Journal of Finance, Vol 11, pp. 531-548.

Hartono J., dan Sulistiawan, D., 2014, “The Market Quality to Technical A nalysis Performance: Intercountry A nalysis", Gadjahmada International Journal of Business, Vol 16, pp. 243-254.

Ho, Y., dan Sequeira, J.M, 2007, “Earnings Surprises, A symmetry of Returns, and Market-Level Changes: An Industry Study", Journal of Accounting, A uditing, and Finance, $\mathrm{Vol} 20$, pp. 29-55.

Kassin S.M., Dror I.E., dan Kukucka J., 2013, “The Forensic Confirmation Bias: Problems, Perspectives and Proposed Solutions", Journal of A pplied Research in M emory and Cognition, Vol 2, pp. 42-52. 


\section{Jurnal Keuangan dan Perbankan | KEUANGAN}

Vol. 19, N o.3, September 2015: 400-408

Libby, R., dan Tan H., 1999, “A nalysts' Reaction to Warnings of Negative Earnings Surprises", Journal of A ccounting Research, Vol 37, pp. 415-435.

McKenzie, M.D., 2007, “Technical Trading Rules in Emerging Markets and The 1997 A sian Currency Crises", Emerging $M$ arkets Finance and Trade, Vol 43, pp. 46-73.

Metghal chi, M ., Chang, Y., dan Gomez, XG., 2012, “Technical Analysis of The Taiwanese Stock Market", International Journal of Economics and Finance, $\mathrm{Vol} 4$, pp. 90-102.

Mian, G.M., dan Sankaraguruswamy S., 2012, "Investor Sentiment and Stock Market Response to Earnings News", A ccounting Review, Vol 87, pp. 13571384.

Milionis, A.E., dan Papanagiotou, E., 2008, “On the Use of Moving Average Trading Rule Test for Weak Form Efficiency in Capital Markets", Review of Banking. Financeand M onetary E conomics, Vol 2, pp. 181201.

Odean, Terrance, 1998, “A re Investors Reluctant to Realize Their Losses", Journal of Finance, Vol 53, pp. 1775-1798.

Shefrin, H., dan Statman, M., 1984, “The Disposition to Sell Winners Too Early and Ride Losers too Long: Theory and Evidence", Journal of Finance, $\mathrm{Vol} 40$, pp. $777-790$.

Simon H.A., 1972, "Theories of Bounded Rationality", Decision and Organization, McGuire and Roy Radner (Eds), N orth-Holland.
Sugiri, Slamet, dan Sumiyana, 2009, “Evidence of Assymetric Price Reaction from Emerging Capital Market", The Indonesian Journal of A ccounting Research, Vol 12, pp. 177-194.

Sulistiawan D., dan Hartono, J., 2014, “Can Technical Analysis Signals Detect Price Reaction A round Earnings Announcements?: Evidence from Indonesia, The International Journal of Business and Finance Research, Vol 8, pp. 113-123.

Sulistiawan, D., Hartono J., Tandelilin, E., dan Supriyadi, 2014, “Earnings Announcements and Competing Information: The Indonesian Evidence", The Indonesian Journal of Economy and Business,, ol 29

Sweeney, R.J., 1988, “Some New Filter Rule Tests: Methods and Results", Journal of Financial and Q uantitative A nalysis, Vol 23, pp. 285-300.

Weber, M., dan Camerer, C.F., 1998, "The Disposition Effect in Securities Trading: an Experimental Analysis", Journal of Economic Behavior and Organization, Vol 33, pp. 167-184.

Wong, W., Manzur, M., dan Chew, B., 2003, "How Rewarding is Technical Analysis? Evidence from SingaporeStock Market", A pplied Financial Economics, Vol 13, pp. 543-551.

Xu, Weihong, 2008, "Market Reactions to Warnings of Negative Earnings Surprises: Further Evidence", Journal of Business Finance and A ccounting, Vol 35, pp. 818-836. 